\title{
An assessment of the effectiveness of a large, national-scale invasive alien plant control strategy in South Africa
}

\author{
Brian W. van Wilgen ${ }^{\mathrm{a}, *}$, Greg G. Forsyth ${ }^{\mathrm{a}}$, David C. Le Maitre ${ }^{\mathrm{a}}$, Andrew Wannenburgh ${ }^{\mathrm{b}}$, \\ Johann D.F. Kotzéc ${ }^{c}$, Elna van den Berg ${ }^{c}$, Lesley Henderson ${ }^{d}$ \\ ${ }^{a}$ Centre for Invasion Biology, CSIR Natural Resources and the Environment, P.O. Box 320, Stellenbosch 7599, South Africa \\ ${ }^{\mathrm{b}}$ National Working for Water Program, Department of Environmental Affairs, Private Bag X4390, Cape Town 8000, South Africa \\ ${ }^{\mathrm{c}}$ Institute for Soil, Climate and Water, Agricultural Research Council, Private Bag X79, Pretoria 0001, South Africa \\ ${ }^{\mathrm{d}}$ Plant Protection Research Institute, Agricultural Research Council, c/o SANBI, Private Bag X101, Pretoria 0001, South Africa
}

\section{A R T I C L E I N F O}

\section{Article history:}

Received 26 August 2011

Received in revised form 30 November 2011

Accepted 16 December 2011

Available online 18 February 2012

\section{Keywords:}

Adaptive management

Biological control

Biological invasions

Ecosystem services

Invasive alien species

Working for Water

\begin{abstract}
A B S T R A C T
This paper presents an assessment of a large, national-scale alien plant control program that has operated in South Africa for 15 years. We reviewed data from three national-level estimates of the extent of invasion, records of the costs and spatial extent of invasive species control operations, assessments of the effectiveness of biological control, and smaller-scale studies. The 19 most important invasive taxa, mainly trees, in terrestrial biomes were identified. The effectiveness of control efforts on the extent of invasion of these taxa was assessed. Control costs over 15 years amounted to 3.2 billion rands (US\$457 million), more than half of which was spent on 10 taxa, the most prominent being in the genera Acacia, Prosopis, Pinus and Eucalyptus. Despite substantial spending, control operations were in many cases applied to a relatively small portion of the estimated invaded area, and invasions appear to have increased, and remain a serious threat, in many biomes. Our findings suggest that South Africa's national-scale strategy to clear invasive alien plants should be substantially modified if impacts are to be effectively mitigated. Rather than attempting to control all species, and to operate in all areas, a more focused approach is called for. This would include prioritising both the species and the areas, and setting goals and monitoring the degree to which they are achieved, within a framework of adaptive management. A greater portion of funding should also be directed towards biological control, where successes have been most notable.
\end{abstract}

(c) 2012 Elsevier Ltd. All rights reserved.

\section{Introduction}

Alien plant invasions are a large and growing threat to ecosystem integrity in many parts of the world, where they change the structure and functioning of ecosystems, with negative consequences for the conservation of biodiversity and the delivery of ecosystem services (Mooney, 2005). There are several examples of high-level strategies to deal with the problem of invasive alien species, both at global (McNeely et al., 2001) and national levels (Federal Interagency Committee, 1998; Anonymous, 1999). These strategies all call for reducing the risk of new introductions of invasive species, the control of existing invasions to mitigate impact, and the establishment of management and legislative capacity to guide implementation. Interventions that give effect to national strategies are often a major component of the management of terrestrial ecosystems (Wittenberg and Cock, 2005), and attempts

\footnotetext{
* Corresponding author. Tel.: +27 21888 2400; fax: +27 218882693 .

E-mail address: bvwilgen@csir.co.za (B.W. van Wilgen).
}

to control invasive species can and have brought about substantial levels of mitigation (Simberloff et al., 2011).

In South Africa, the strategy over the past 15 years has been to implement a large, national-scale, government-sponsored alien plant control program (van Wilgen et al., 1998, 2011a; Koenig, 2009). Known as 'Working for Water', the program has adopted a comprehensive approach to alien plant control, characterised by several distinguishing features. The program combines mechanical and chemical control of all invasive alien plant species in targeted areas with the provision of employment to people from impoverished rural communities as its main thrust. This has been supplemented by (1) the development of biological control options that target selected priority alien plant species (Zimmermann et al., 2004; Moran et al., 2005); (2) the promulgation of legislation that requires landowners to deal with the problem (van Wilgen et al., 2011a); and (3) the encouragement of systems of payment for ecosystem services that will generate funding to support control programs (Turpie et al., 2008). Few countries have implemented similar control programs, and we are not aware of any that have 
assessed the effectiveness of such operations at a national scale over one and a half decades.

When Working for Water was initiated in 1995, an attempt was made to quantify the extent of invasions at a national scale (Versfeld et al., 1998), to provide inputs for management planning (see, for example, Le Maitre et al., 2002), to assist in the quantification of impacts (Le Maitre et al., 2000), and to serve as a baseline against which to assess trends. Working for Water has since spent 3.2 billion rands (expressed as 2008 rands, approximately 457 million US\$) on alien plant control. Whether or not the correct, top-priority, species are being targeted, and whether or not progress has been made in reducing the extent of invasions, remains uncertain. While Working for Water has kept records of expenditure per species and geographic area since 2002, the ability to address questions regarding the effectiveness of their operations is limited because the program has not implemented an effective system of monitoring and evaluation (Levendal et al., 2008). A preliminary assessment of progress (Marais et al., 2004) was made by comparing the rate of clearing to the rough approximations of invaded area in 1996. Marais et al. (2004) concluded that, at the prevailing rates of clearing, and depending on the species, it would take between two and 83 years to clear the most important species, but with the important, albeit unrealistic, assumption that no further spread would take place during this time.

Working for Water has taken several steps to assess trends and changes in the situation. These include the commissioning in 2005 of a second national-scale assessment of the extent of invasion (Kotzé et al., 2010), providing ongoing financial support to a national-scale atlas project (Henderson, 2007), and supporting (or acting as a catalyst for) several finer-scale research projects. The study reported in this paper used information from all of the above sources to assess the effectiveness of Working for Water in suppressing and controlling invasive alien plants in South Africa, and we propose improvements that could increase efficacy and success.

\section{Methods}

\subsection{Studies by biome}

Working for Water is a national-level initiative in South Africa, operating in all nine of the country's provinces and across all major terrestrial biomes. The country's indigenous vegetation is diverse, including nine terrestrial biomes, and high levels of endemism are a feature of several biomes (Mucina and Rutherford, 2006). We used biomes as a basis for our assessment, as each biome is characterised by particular features (e.g. fire and rainfall regimes, and levels of herbivory), and is invaded by distinctive suites of alien plant species (Table 1). Much of the natural vegetation remains untransformed, and provides important ecosystem services in the form of livestock production from rangelands, water production from mountain catchments, and conservation and tourism benefits from protected and other areas. All of these services are under considerable threat from invasive alien plants (van Wilgen et al., 2008a). While invasive alien plants can bring benefits, these benefits are, by and large, outweighed by the negative impacts (see, for example, De Wit et al., 2001; van Wilgen et al., 2011b).

\subsection{Extent of invasions}

There have been three national-scale, and several smaller-scale, estimates of the extent of alien plant invasion in South Africa, compiled over the past 15 years. We used these estimates to identify the most important species involved and to assess, within the limits of the data (see Section 2.6) the extent to which they have impacted on the terrestrial biomes of South Africa.
The first estimate was initiated in 1994 through the Southern African Plant Invaders Atlas (SAPIA, Henderson, 1998). SAPIA is an ongoing project, which aims to collate information on the distribution and abundance of invasive and naturalised alien plants in southern Africa. Initially, the atlas was populated with data collected during roadside surveys, but was later broadened to accept inputs from volunteers, who were supplied with survey sheets to ensure the standardisation of inputs. By 2011, the SAPIA database contained approximately 72,300 records of alien plant species presence and abundance within quarter degree squares (a grid of approximately $25 \times 25 \mathrm{~km}$ ). Henderson (2007) used the SAPIA database to estimate a prominence value for each species, calculated as $P_{i}=A_{i} / A+R_{i} / R$ where $P_{i}=$ the prominence of species $i$ in a particular area, $A_{i}=$ the abundance of species $i, A=$ the abundance of all species, $R_{i}=$ the total number of records of species $i$ and $R=$ the total number of records of all species.

The second estimate was made in 1996 (Versfeld et al., 1998; Le Maitre et al., 2000). Data on the extent and location of the areas invaded by all important invasive alien plant taxa were obtained from a variety of sources for this survey, including some detailed field mapping, mainly at a 1:250,000 scale, with some at 1:50,000 and at $1: 10,000$. The species data were captured, together with estimates of their density for each of the mapped areas, in a GIS database. We converted these density estimates to $100 \%$ equivalent cover ("condensed ha") for comparison to other surveys, using the formula $C=d / 100 \times A$, where $C$ is the area expressed as condensed ha, $d$ is the density (\% cover), and $A$ is the area in ha within which the density was assessed. The authors of the survey noted that the findings were approximations, and needed to be interpreted with caution.

A third estimate in 2008 mapped 27 alien plant taxa (Kotzé et al., 2010). Species in the genera Pinus and Eucalyptus and some Acacia were mapped collectively. Prior to the survey, the entire country (excluding most of the arid biomes - Desert, Nama karoo, succulent karoo, and arid portions of the grassland and savanna biomes - and the Kruger National Park) was divided into homogenous environmental units (HEUs), based on unique combinations of three classes of rainfall, soil depth, clay content in the B-horizon of the soil, and two classes of terrain in each tertiary (3rd order) catchment. Those portions of HEUs that had been transformed were excluded. The remaining portions of the HEUs were then sampled at 32,330 points. Points were allocated to HEUs in proportion to their area, and then located at random within HEUs. At each sample point, the percentage cover of the three dominant alien plant taxa was estimated from low-flying fixed-wing light aircraft or helicopters on $100 \times 100 \mathrm{~m}$ plots by observers who were familiar with invasive species in the area. A second set of 25,260 sample points were located on a grid of $1600 \times 1600 \mathrm{~m}$ in a subsample of 205 quaternary (4th order) catchments (about 10\% of the country), and results from this survey were used to verify broad levels of invasion detected in the national survey. Survey data were used to estimate mean percentage cover and coefficient of variation for each of the taxa in each HEU in each catchment. Areas were expressed as equivalent to $100 \%$ canopy cover (condensed ha, see above).

We obtained estimates of the extent of invasion per biome by creating subsets of the spatial databases described above using Mucina and Rutherford's (2006) biome boundaries. In the case of the SAPIA database, a biome-scale analysis of the data was already available (Henderson, 2007). Our analysis excluded the arid portions of the grassland and savanna biomes, which were not covered by Kotzé et al.'s (2010) survey. A recent estimate of the extent of invasion by Prosopis species was available for the Northern Cape Province (which includes large portions of the succulent karoo, Nama karoo, arid grasslands and arid savannas) (van den Berg, 2010). Control in these biomes has focussed almost entirely on 
Table 1

Features of the terrestrial biomes in South Africa, and the major invasive alien species in each biome. Data are from Mucina and Rutherford (2006) and Henderson (2007).

\begin{tabular}{|c|c|c|c|c|}
\hline Biome & $\begin{array}{l}\text { Extent } \\
\left(\mathrm{km}^{2}\right)\end{array}$ & $\begin{array}{l}\text { Portion of biome } \\
\text { remaining } \\
\text { untransformed } \\
(\%)\end{array}$ & Features & Prominent invasive alien plant species \\
\hline Fynbos & 83,964 & 69 & $\begin{array}{l}\text { Mediterranean-climate, fire-prone, } 1-2 \mathrm{~m} \text { tall shrublands on } \\
\text { nutrient-poor soils. High levels of diversity and endemism } \\
\text { among plant species }\end{array}$ & $\begin{array}{l}\text { Trees and shrubs in the genera Acacia (wattles), Pinus } \\
\text { (pines) and Hakea (shrubs in the family Proteaceae) }\end{array}$ \\
\hline Grassland & 354,953 & 65 & $\begin{array}{l}\text { Short-stature, relatively species-rich vegetation dominated by } \\
\text { grasses and forbs, with few woody life-forms present. Prone to } \\
\text { frequent fire and subject to high levels of grazing }\end{array}$ & $\begin{array}{l}\text { Important trees include wattles (Acacia species), } \\
\text { willows (Salix species), poplars (Populus species) and } \\
\text { gums (Eucalyptus species), notably along rivers. Shrubs } \\
\text { include Rubus species (brambles), Pyracantha species } \\
\text { (firethorns) and cacti (Opuntia species) }\end{array}$ \\
\hline Savanna & 412,544 & 77 & $\begin{array}{l}\text { Characterised by the co-dominance of trees and grasses. The } \\
\text { portion of trees to grasses is determined largely by four } \\
\text { interacting factors: soil fertility, rainfall, fire and grazing } \\
\text { pressure. Our analysis divided savanna into arid and moist areas } \\
\text { to accommodate comparisons to other surveys that used similar } \\
\text { divisions }\end{array}$ & $\begin{array}{l}\text { Invasive species are dominated by the shrubs } \\
\text { Chromolaena odorata (L.) R.M. King \& H. Rob. (triffid } \\
\text { weed) and Lantana camara L. (lantana). Important } \\
\text { invasive trees include wattles (Acacia species), Melia } \\
\text { azederach L. (syringa), Solanum maurtitianum Scop. } \\
\text { (bugweed), Psidium guajava L. (guava) and Jackaranda } \\
\text { mimosifolia D. Don. (jackaranda). Trees in the genus } \\
\text { Prosopis (mesquite) are predominant in arid parts }\end{array}$ \\
\hline $\begin{array}{l}\text { Albany } \\
\text { thicket }\end{array}$ & 29,127 & 88 & $\begin{array}{l}\text { Dense, woody, semi-succulent and thorny vegetation, } 2-3 \mathrm{~m} \\
\text { tall. Essentially fire-free due to low amounts of dead dry } \\
\text { material and high portion of succulents }\end{array}$ & $\begin{array}{l}\text { Invasive succulents, mainly cacti (Opuntia and related } \\
\text { genera) with Acacia and Eucalyptus species along the } \\
\text { rivers }\end{array}$ \\
\hline $\begin{array}{l}\text { Nama } \\
\text { karoo }\end{array}$ & 248,728 & 98 & $\begin{array}{l}\text { Low, dwarf shrublands, with co-occurring grasses, succulents, } \\
\text { geophytes and annuals. Small trees occur along drainage lines }\end{array}$ & $\begin{array}{l}\text { Trees in the genus Prosopis (mesquite). The shrub } \\
\text { Atriplex lindleyi Moq. subsp. inflata (F. Müll.) P.G. Wilson } \\
\text { (sponge-fruit salt-bush) and the cactus Opuntia ficus- } \\
\text { indica (L.) Mill. (sweet prickly pear) are also } \\
\text { predominant. The tree Schinus molle L. (pepper tree) is } \\
\text { becoming increasingly widespread. }\end{array}$ \\
\hline $\begin{array}{l}\text { Succulent } \\
\text { karoo }\end{array}$ & 83,283 & 95 & $\begin{array}{l}\text { Highly diverse low dwarf shrublands with many succulents, } \\
\text { geophytes and annuals and low perennial plant cover. The } \\
\text { world's only arid biodiversity hotspot }\end{array}$ & $\begin{array}{l}\text { Trees in the genera Acacia (wattles), Prosopis (mesquite) } \\
\text { and Populus (poplars), and the shrubs Nicotiana glauca } \\
\text { Graham (wild tobacco) and Atriplex lindleyi Moq. subsp. } \\
\text { inflata (F.Müll.) P.G.Wilson (sponge-fruit salt-bush) and } \\
\text { A. nummularia Lindl. (old man saltbush). The cactus } \\
\text { Opuntia ficus-indica (L.) Mill. (sweet prickly pear) is also } \\
\text { predominant }\end{array}$ \\
\hline $\begin{array}{l}\text { Indian } \\
\text { Ocean } \\
\text { coastal } \\
\text { belt }\end{array}$ & 14,282 & 51 & $\begin{array}{l}\text { Mixed vegetation characterised by juxtaposed fire-prone } \\
\text { grasslands and savannas, and fire-free forests }\end{array}$ & $\begin{array}{l}\text { The herbaceous shrubs Chromolaena odorata and } \\
\text { Lantana camara are the most important invasive } \\
\text { species. Additional species include Caesalpinia } \\
\text { decapetala, Cestrum laevigatum and Psidium guajava L. } \\
\text { (guava) }\end{array}$ \\
\hline Forest & 4731 & 94 & $\begin{array}{l}\text { Multilayered vegetation dominated by evergreen trees, ranging } \\
\text { in height from } 3 \mathrm{~m} \text { to } 30 \mathrm{~m} \text {. Occurs as scattered, fire-free patches } \\
\text { of varying size }\end{array}$ & $\begin{array}{l}\text { Dominant invasive trees include wattles (Acacia } \\
\text { species) and Solanum mauritianum Scop. (bugweed). } \\
\text { Chromolaena odorata (L.) R.M. King \& H. Rob. (triffid } \\
\text { weed) and Lantana camara are important invasive } \\
\text { shrubs }\end{array}$ \\
\hline Desert & 7166 & 99 & $\begin{array}{l}\text { Dry areas ( }<70 \mathrm{~mm} \text { mean annual rainfall) with sparse perennial } \\
\text { vegetation of }<10 \% \text { cover }\end{array}$ & Invasions of Prosopis (mesquite) trees in dry river beds \\
\hline
\end{tabular}

Prosopis species, so we restricted our assessment in these biomes to the clearing of Prosopis species in the Northern Cape Province.

A number of finer-scale studies were used to provide insights into trends in the extent of invasion in South Africa, and into the effectiveness of control operations. These included Esler et al. (2010) for Hakea species in the fynbos biome, Moeller (2010) for Pinus species in the Eastern Cape Province, and Otten (2010) for Acacia cyclops in the Western Cape Province.

\subsection{Selection of invasive alien plant taxa}

We focussed our assessment on the most important invasive alien plant taxa. These taxa were defined as the top 10 in terms of area occupied in the estimates of Le Maitre et al. (2000) and Kotzé et al. (2010), and the top 10 in terms of prominence value as defined by Henderson (2007; see Section 2.2). In addition, we ranked taxa in each biome in terms of the cost of control, and included the highest-ranked taxa that jointly accounted for at least $85 \%$ of control costs in any given biome. Authorities for species names, and common names, are provided in Tables 1 and 2, or at first mention in the text for species not in Tables 1 or 2 .

\subsection{Costs of control}

The costs of control have been recorded by Working for Water in a spatially-explicit database since 2002 (Marais et al., 2004). All of Working for Water's control operations are carried out by contractors. The records include the species treated and the direct costs paid out to contractors. As the records do not contain Working for Water's overheads, we assumed that overhead costs (funds spent by Working for Water minus funds paid to contractors for each year) were distributed among taxa in the same proportion as the expenditure on the control of individual taxa. The costs of herbicides were not recorded in the contractor database, and we included these in overheads. We further assumed that funds expended prior to 2002 (1995-2001) were allocated to the control of individual species in the same proportions as funds expended after 2002. Finally, we used the consumer price index to inflate all costs to 2008 rands to account for inflation ( 1 US\$ = approximately 7 South African rands). We used 2008 as a base year to allow for direct comparisons between expenditure and the estimates of invasion up to that year. 
Table 2

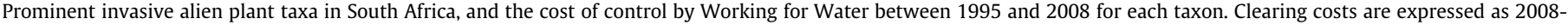
equivalent rands ( 1 US\$ = approximately 7 South African rands).

\begin{tabular}{|c|c|c|c|c|c|}
\hline Invasive alien plant taxon & Growth form & $\begin{array}{l}\text { Rank in terms of area } \\
\text { occupied (Le Maitre et al., } \\
\text { 2000). }\end{array}$ & $\begin{array}{l}\text { Rank in terms of area } \\
\text { occupied (Kotzé et al., } \\
\text { 2010) }\end{array}$ & $\begin{array}{l}\text { Rank in terms of prominence } \\
\text { value (Henderson, 2007) }\end{array}$ & $\begin{array}{l}\text { Clearing cost } \\
\text { (millions of } \\
\text { rands) }\end{array}$ \\
\hline $\begin{array}{l}\text { Acacia cyclops A.Cunn. ex } \\
\text { G.Don (rooikrans) }\end{array}$ & Evergreen tree & 1 & 7 & 4 & 58.0 \\
\hline A. dealbata Link (silver wattle) & Evergreen tree & 12 & $\begin{array}{l}1 \text { (grouped with other } \\
\text { wattle species) }\end{array}$ & 10 & 79.3 \\
\hline $\begin{array}{l}\text { A. mearnsii De Wild. (black } \\
\text { wattle) }\end{array}$ & Evergreen tree & 3 & $\begin{array}{l}1 \text { (grouped with other } \\
\text { wattle species) }\end{array}$ & 1 & 561.9 \\
\hline $\begin{array}{l}\text { A. melanoxylon R.Br. } \\
\text { (blackwood) }\end{array}$ & Evergreen tree & 26 & 25 & 25 & 28.0 \\
\hline $\begin{array}{l}\text { A. saligna (Labill.) H.L. Wendl. } \\
\text { (Port Jackson Willow) }\end{array}$ & Evergreen tree & 4 & 8 & 2 & 88.4 \\
\hline Arundo donax $\mathrm{L}$. & Robust reed & 34 & 24 & 12 & 8.2 \\
\hline $\begin{array}{c}\text { Caesalpinia decapetala (Roth) } \\
\text { Alston (Mauritius thorn) }\end{array}$ & Evergreen shrub & 16 & 18 & 27 & 33.2 \\
\hline $\begin{array}{l}\text { Cereus jamacaru DC. (queen of } \\
\text { the night) }\end{array}$ & $\begin{array}{l}\text { Spiny succulent } \\
\text { tree }\end{array}$ & Not reported & 17 & 51 & 57.5 \\
\hline $\begin{array}{l}\text { Chromolaena odorata (L.) } \\
\text { R.M.King \& H.Rob. (triffid } \\
\text { weed) }\end{array}$ & Scrambling shrub & 14 & 4 & 11 & 171.8 \\
\hline Eucalyptus species (gum trees) & Evergreen trees & 11 & 2 & 13 & 237.0 \\
\hline $\begin{array}{l}\text { Hakea sericea Schrad. \& } \\
\text { J.C.Wendl. (silky hakea) }\end{array}$ & Evergreen shrub & 10 & 11 & 41 & 69.3 \\
\hline Lantana camara L. (lantana) & Scrambling shrub & 9 & 12 & 3 & 180.6 \\
\hline Melia azederach L. (syringa) & Deciduous tree & 8 & 13 & 9 & 41.5 \\
\hline Cactaceae & $\begin{array}{l}\text { Spiny, succulent } \\
\text { trees and shrubs }\end{array}$ & 7 & 5 & 5 & 23.3 \\
\hline Pinus species (pine trees) & Evergreen trees & 6 & 3 & 14 & 183.5 \\
\hline Populus species (poplar trees) & Deciduous trees & 24 & 6 & 7 & 42.5 \\
\hline Prosopis species (mesquite) & Evergreen trees & 2 & Not reported & 12 & 435.5 \\
\hline $\begin{array}{l}\text { Salix babylonica L. (weeping } \\
\text { willow) }\end{array}$ & Evergreen tree & 25 & 10 & 8 & 8.1 \\
\hline $\begin{array}{l}\text { Solanum mauritianum Scop. } \\
\text { (bugweed) }\end{array}$ & $\begin{array}{l}\text { Evergreen shrub } \\
\text { or small tree }\end{array}$ & 5 & 9 & 6 & 121.5 \\
\hline
\end{tabular}

\subsection{Extent of control}

Working for Water's contractor database contains the following records for each site: the species being treated, the area treated (captured spatially at a scale of at least $1: 15,000$ ), and the density of the infestation (based on aerial canopy cover). For each biome, we determined the area that had been treated for each of the selected invasive alien plant taxa (including initial treatment and all follow-up treatments, where applicable). We converted the density values to $100 \%$ equivalent cover (condensed ha, see Section 2.2 above).

\subsection{Trends in alien plant cover}

An understanding of trends in alien plant cover is needed to assess whether control efforts are sufficient to stem the spread or reduce the degree of invasion by alien plants or, if insufficient, to estimate the control effort that would be needed to bring the species under control. Ideally, such assessments should be done by comparing the degree of invasion over time in successive estimates that use the same approach. However, in our study, such direct comparisons were not possible because of the different approaches used in making the estimates. We therefore assessed trends for the most important alien plant species using estimates from the two national surveys (Le Maitre et al., 2000; Kotzé et al., 2010) and the estimates of extent of control, as indicators and not as comparable estimates. The emergence of new, rapidly-spreading invasive species was assessed using the rate of addition of records to the SAPIA database. In addition, postrelease monitoring of biological control agents provided further insights into the effectiveness of control (Klein, 2011; Moran and Hoffmann, 2011).

\section{Results}

\subsection{Extent of invasions and prominent taxa}

Invasive alien plants were estimated to occupy approximately 1.736 million condensed ha in 1996 (Le Maitre et al., 2000). By combining the estimates of Kotzé et al. (2010) and van den Berg (2010) (which are from mutually exclusive areas that together cover most of the country), the estimated extent of invasion in 2008 was approximately 1.813 million condensed ha. While these estimates are not directly comparable (Section 2.6) the similarity of the estimates suggest that invasions have not decreased. Records in the SAPIA database indicate that alien plant invasions occur throughout South Africa, but are concentrated in the southwestern, southern and eastern coastal belts and the adjacent interior, which are also the areas of highest rainfall (Henderson, 2007).

We focussed on 19 invasive alien plant taxa in this assessment (Table 2). Of these, 15 were identified by merging the lists of the 10 most important taxa in either Le Maitre et al. (2000), Henderson (2007) or Kotzé et al. (2010). A further four were added because, despite their lower prominence, they were targeted for clearing and attracted a substantial portion of clearing costs in at least one biome. These were Arundo donax, Acacia melanoxylon, Cereus jamacaru and Caesalpinia decapetala, targeted for control in thicket, forest, moist savanna and the Indian Ocean coastal belt biomes respectively. Almost all prominent taxa (15) were either trees or shrubs (Table 2).

\subsection{Costs of control}

The costs of control by Working for Water between its inception in 1995 and the end of 2008 amounted to 3.2 billion rands 
(expressed as 2008 rands). Most (66\%) of the funds were spent on the top 10 taxa, with the remainder divided among 95 less prominent taxa. The largest portion of funding (561.9 million rands) was spent on the control of Acacia mearnsii. If this is added to the costs associated with the closely-related wattle species Acacia dealbata (cost of 79.3 million rands), the costs of control of these two species accounted for $19.4 \%$ of the costs of all alien plant control. A total of 435.5 million rands was spent on the next most-targeted taxon (Prosopis species), while 237.0 and 183.5 million rands were spent on Eucalyptus and Pinus species respectively. The remaining taxa in the top 10 (and costs of control in millions of rands) were Lantana camara (180.6), Chromolaena odorata (171.8), Solanum mauritianum (121.5), Hakea species (69.0) and A. cyclops (58.0). The number and identity of the taxa attracting the highest clearing costs varied between the biomes (Table 3 ).

\subsection{Assessment of control achieved in biomes}

\subsubsection{Fynbos biome}

Control efforts may have reduced the extent of invasion of some, but not all, of the species selected for our assessment in the fynbos biome. A relatively small portion (3.9\% and $5.7 \%$ ) of the 2008 estimated extent of $A$. cyclops and Acacia saligna respectively has been subjected to control treatments (Table 3 ), but the species may have declined in abundance as a result of the combined effects of substantial but unrecorded clearing by firewood cutters (not accounted for in Working for Water's records) and a substantial degree of biological control (Table 4; see also Otten, 2010). Similarly, there are indications that Hakea species have declined because of historic (pre-1995) mechanical clearing, ongoing clearing by Working for Water, and a substantial degree of biological control (Esler et al., 2010). Both Acacia longifolia (Andr.) Willd. (long-leaved wattle) and A. saligna and were previously considered to be among the five most important invasive plant species in the biome (Macdonald and Jarman, 1984). The extensive monocultures of large, 8-m tall $A$. saligna trees that previously dominated lowland fynbos areas have almost completely disappeared as a result of biological control using a rust pathogen, and the species survives only as patchy, but still problematic, clusters of diseased shrubs (Moran and Hoffmann, 2011). In the case of A. longifolia, biological control has reduced the relative importance of the weed to no more than "an incidental or trivial problem" (Moran and Hoffmann, 2011).

On the other hand, there is no indication that the extent of invasion by either A. mearnsii or Pinus species has decreased in the fynbos biome, despite substantial spending on the problem. Control operations costing 264 million rands have reached about $13 \%$ of the estimated area occupied by these species in 2008 (and more before records began), yet these species remain prominent. One study in the eastern fynbos biome (Moeller, 2010) estimated that the cover of invasive Pinus had more than doubled (from 13.4\% to $28.7 \%$ ) between 1986 and 2007. Gains made in the control of Hakea species are being offset by invasion by Pinus species, which are equally successful invaders of the same areas. Biological control may become more effective in future as the agents on $A$. mearnsii spread and deplete seed loads, but no such solution is available for Pinus (Table 4). In particular, the rugged and inaccessible mountain areas are most vulnerable to invasion by Pinus species, and this poses the most significant threat to the integrity of fynbos ecosystems (Hoffmann et al., 2011; Kraaij et al., 2011).

\subsubsection{Grassland biome}

Most of the control effort in grassland has been focussed on Acacia species (Table 3 ), but control operations have only reached $9 \%$ of the 2008 estimated area occupied by Acacia invasions. There appears to be no detectable decline in the estimated extent of invasion by Acacia species between 1996 and 2008, suggesting that control operations may not be keeping pace with invasion rates. Both Salix babylonica and Populus species (prominent invaders of riparian zones) received hardly any control, and appear to have increased. In addition, the grassland biome is vulnerable to invasion from non-woody plants. These were not included in our assessment as they have not been subjected to any substantial degree of control. For example, several species in the genus Rubus (thorny shrubs), and the herbaceous Cirsium vulgare (Savi) Ten. (Scotch thistle) are prominent invaders of grasslands (Henderson, 2007). In addition, the perennial herb Campuloclinium macrocephalum (Less.) D.C. (pompom weed) has recently undergone spectacular expansion in grasslands. Records from the SAPIA database show that it spread from 48 to 93 quarter degree squares between 2005 and 2010. Grasslands thus remain under significant threat from invasions despite considerable clearing efforts.

\subsubsection{Savanna biome}

Alien plant control efforts in the savanna biome were focussed on more taxa than other biomes (Table 3). Species of Cactaceae (including C. jamacaru) appear to have declined (Table 3), but much of this may be due to biological control rather than mechanical clearing. Despite spending over 512 million rands on the remaining prominent taxa, it was only possible to treat a relatively small portion (2.2-22\%) of their estimated 2008 invasions. The exception was Lantana camara, where $49 \%$ of the 2008 estimated area was treated, and the extent of invasion may have declined. For other species, notably A. mearnsii and C. odorata, large increases between the 1996 and 2008 estimates of invaded area (Table 3), and in the increase in the number of records in the SAPIA database (67\% since 1996 in the case of Chromolaena), suggest that the extent of invasion may have increased despite control efforts. New invaders are also emerging in savannas, including Tecoma stans (L.) Kunth. (yellow bells), an ornamental shrub or small tree, that has more than tripled its extent from 28 known quarter degree squares in 1996 to 86 quarter degree squares in 2011.

\subsubsection{Forest biome}

Alien plant control operations in the forest biome focussed on trees in the genera Acacia, Eucalyptus and Pinus (Table 3). Forests only cover $0.38 \%$ of South Africa (Table 1 ), with a scattered distribution. The scale of mapping used in various surveys is relatively coarse compared to the distribution of forests, and it is therefore not possible to draw confident conclusions regarding the success of control operations in the forest biome.

\subsubsection{Albany thicket biome}

Alien plant control operations in the thicket biome focussed on four taxa (Table 3 ), of which only two (A. mearnsii and Cactaceae species, mainly Opuntia ficus-indica) were prominent invaders in the biome. The control operations reached only a very small portion of the 2008 estimated invasions (1\% of A. mearnsii and $0.1 \%$ of Cactaceae species respectively, Table 3 ), suggesting that mechanical clearing would not have kept up with spread of these species. Biological control of Opuntia ficus-indica, which is assessed as 'substantial' in South Africa (Klein, 2011), is 'relatively ineffective' in areas of higher rainfall, including the thicket biome (Zimmermann and Moran, 1991). The effectiveness of two biological control agents on A. mearnsii is not known, and one has only recently been released (Impson et al., 2008), and is not yet present in the thicket biome.

\subsubsection{Indian Ocean coastal biome}

C. odorata is the most dominant invasive species in this biome, and it has received the bulk of funding for control costs (Table 3 ). Although almost half (46\%) of the estimated invaded area has been 
Table 3

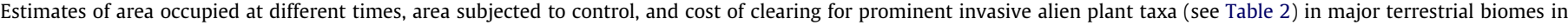

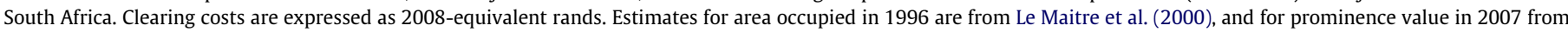
Henderson (2007). Estimates for 2008 are from van den Berg (2010) for Prosopis species and Kotzé et al. (2010) for all other taxa.

\begin{tabular}{|c|c|c|c|c|c|c|}
\hline \multirow[t]{2}{*}{ Biome } & \multirow{2}{*}{$\begin{array}{l}\text { Invasive alien } \\
\text { plant taxon }\end{array}$} & \multicolumn{3}{|c|}{ Estimated area occupied } & \multicolumn{2}{|l|}{ Control effort } \\
\hline & & $\begin{array}{l}\text { In } 1996 \\
\text { (condensed } \\
\text { ha } \times 1000 \text { ) }\end{array}$ & $\begin{array}{l}\text { In } 2007 \\
\text { (prominence } \\
\text { value) }\end{array}$ & $\begin{array}{l}\text { In } 2008 \text { (condensed } \\
\text { ha } \times 1000, \pm C V \%)\end{array}$ & $\begin{array}{l}\text { Area treated between } 2002 \text { and } \\
2008 \text { (condensed ha } \times 1000 \text { ) }\end{array}$ & $\begin{array}{l}\text { Cost of treatment between } 1995 \\
\text { and } 2008 \text { (millions of rands) }\end{array}$ \\
\hline \multirow[t]{6}{*}{ Fynbos } & Acacia cyclops & 285.6 & 27.2 & $48.4( \pm 12.1)$ & 1.9 & 45.3 \\
\hline & A. mearnsii & 45.6 & 31.5 & $27.5( \pm 14.1)$ & 6.7 & 141.0 \\
\hline & A. saligna & 92.3 & 30.40 & $45.6( \pm 12.1)$ & 2.6 & 93.7 \\
\hline & Hakea species & 39.6 & 3.84 & $36.6( \pm 13.6)$ & 4.5 & 69.3 \\
\hline & Pinus species & 50.4 & 11.22 & $58.5( \pm 14.0)$ & 7.4 & 123.3 \\
\hline & Populus species & 3.2 & 3.19 & $1.9( \pm 12.1)$ & 0.3 & 6.7 \\
\hline \multirow{5}{*}{$\begin{array}{l}\text { Grassland } \\
\text { (excluding arid } \\
\text { areas) }\end{array}$} & $\begin{array}{l}\text { Acacia dealbata } \\
\text { and } A \text {. mearnsii }\end{array}$ & 110.1 & 42.2 & $310.8( \pm 14.0)$ & 27.6 & 388.6 \\
\hline & $\begin{array}{l}\text { Eucalyptus } \\
\text { species }\end{array}$ & 118.9 & 7.35 & $157.6( \pm 15.1)$ & 3.9 & 86.0 \\
\hline & Populus species & 5.8 & 14.19 & $43.4( \pm 14.8)$ & 0.7 & 15.4 \\
\hline & Salix babylonica & 6.0 & 17.30 & $34.9( \pm 14.8)$ & 0.4 & 8.7 \\
\hline & $\begin{array}{l}\text { Solanum } \\
\text { mauritianum }\end{array}$ & 41.3 & 10.6 & $7.1( \pm 13.6)$ & 3.5 & 44.0 \\
\hline \multirow{8}{*}{ Moist savanna } & Acacia mearnsii & 28.4 & 10.2 & $103.7( \pm 13.6)$ & 4.1 & 51.2 \\
\hline & Cereus jamacaru & 21.9 & 1.99 & $10.2( \pm 16.2)$ & 21.8 & 66.5 \\
\hline & $\begin{array}{l}\text { Cactaceae } \\
\text { species }\end{array}$ & 47.0 & 11.76 & $18.7( \pm 12.0)$ & 0.5 & 8.1 \\
\hline & $\begin{array}{l}\text { Chromolaena } \\
\text { odorata }\end{array}$ & 23.7 & 14.2 & $73.3( \pm 14.1)$ & 7.8 & 106.1 \\
\hline & $\begin{array}{l}\text { Eucalyptus } \\
\text { species }\end{array}$ & 25.4 & 4.0 & $70.4( \pm 14.9)$ & 4.9 & 113.0 \\
\hline & Lantana camara & 40.3 & 20.6 & $22.5( \pm 14.2)$ & 11.1 & 140.4 \\
\hline & Melia azedarach & 58.8 & 12.00 & $10.0( \pm 15.1)$ & 2.2 & 56.0 \\
\hline & $\begin{array}{l}\text { Solanum } \\
\text { mauritianum }\end{array}$ & 38.1 & 10.6 & $24.8( \pm 15.5)$ & 3.9 & 45.7 \\
\hline \multirow[t]{4}{*}{ Forest } & $\begin{array}{l}\text { Acacia } \\
\text { melanoxylon }\end{array}$ & 1.0 & 14.2 & $0.1( \pm 14)$ & 0.4 & 9.9 \\
\hline & A. mearnsii & 1.1 & 16.7 & $2.1( \pm 11.4)$ & 0.1 & 4.3 \\
\hline & $\begin{array}{l}\text { Eucalyptus } \\
\text { species }\end{array}$ & 0.1 & 7.23 & $1.9( \pm 13.6)$ & 0.2 & 9.1 \\
\hline & Pinus species & 0.2 & 7.86 & $4.2( \pm 12.1)$ & 0.5 & 14.2 \\
\hline \multirow[t]{4}{*}{ Albany thicket } & Acacia mearnsii & 10.5 & $\begin{array}{l}\text { Included in } \\
\text { savanna }\end{array}$ & $17.7( \pm 11.6)$ & 0.2 & 6.7 \\
\hline & Acacia cyclops & 4.9 & $\begin{array}{l}\text { Included in } \\
\text { savanna }\end{array}$ & $0.9( \pm 12.1)$ & 0.06 & 7.5 \\
\hline & Arundo donax & 0.07 & $\begin{array}{l}\text { Included in } \\
\text { savanna }\end{array}$ & $0.2( \pm 14.5)$ & 0.05 & 5.7 \\
\hline & $\begin{array}{l}\text { Cactaceae } \\
\text { species }\end{array}$ & 1.1 & $\begin{array}{l}\text { Included in } \\
\text { savanna }\end{array}$ & $56.4( \pm 12.0)$ & 0.6 & 7.8 \\
\hline \multirow[t]{3}{*}{$\begin{array}{l}\text { Indian Ocean } \\
\text { Coastal Belt }\end{array}$} & $\begin{array}{l}\text { Caesalpinia } \\
\text { decapetala }\end{array}$ & 0.3 & $\begin{array}{l}\text { Included in } \\
\text { savanna }\end{array}$ & $0.4( \pm 12.3)$ & 0.2 & 3.4 \\
\hline & $\begin{array}{l}\text { Chromolaena } \\
\text { odorata }\end{array}$ & 19.3 & $\begin{array}{l}\text { Included in } \\
\text { savanna }\end{array}$ & $19.0( \pm 14.8)$ & 8.8 & 58.0 \\
\hline & Lantana camara & 8.0 & $\begin{array}{l}\text { Included in } \\
\text { savanna }\end{array}$ & $6.0( \pm 12.0)$ & 2.3 & 37.7 \\
\hline $\begin{array}{l}\text { Nama Karoo } \\
\text { (Northern Cape } \\
\text { only) }\end{array}$ & Prosopis species & 104.5 & 78.8 & 252.8 & 8.9 & 220.4 \\
\hline $\begin{array}{l}\text { Succulent karoo } \\
\text { (Northern Cape } \\
\text { only) }\end{array}$ & Prosopis species & 52.0 & 8.9 & 32.1 & 1.1 & 25.9 \\
\hline $\begin{array}{l}\text { Arid savanna } \\
\text { (Northern Cape } \\
\text { only) }\end{array}$ & Prosopis species & 51.3 & $\begin{array}{l}\text { Included in } \\
\text { savanna }\end{array}$ & 51.3 & 3.7 & 139.5 \\
\hline Desert & Prosopis species & 3.9 & $\begin{array}{l}\text { Included in } \\
\text { savanna }\end{array}$ & 7.8 & 1.4 & 49.7 \\
\hline
\end{tabular}

treated over the past 15 years, there is no indication that the extent of the invasion has changed. A considerable effort has been made to find biological control agents for this significant invader species (31 agents have been considered, and 5 released, of which one causes "considerable" damage to the plant, Klein, 2011). The overall degree of biological control achieved has yet to be determined, but is still localised and inconsequential (Table 4). C. odorata therefore remains a large and growing threat to ecosystem integrity in the biome.

\subsubsection{Arid biomes}

Alien plant control operations in all arid areas (the Nama karoo, succulent karoo, desert, and arid portions of savanna and grassland biomes in the Northern Cape Province) focussed on a single taxon (Prosopis species), which accounted for $>85 \%$ of the control costs in all arid biomes. Despite expenditure of 435 million rands, the control was only applied to a very small portion (4\%) of the estimated invaded area (Table 3). It also appears that Prosopis invasions are increasing at an exponential rate despite clearing efforts. The 
Table 4

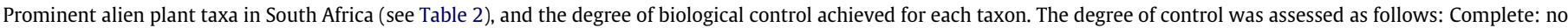

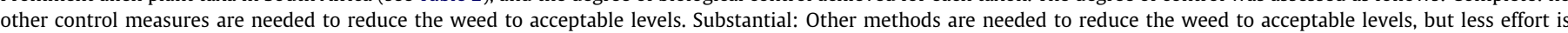
required. Negligible: despite damage, control of the weed remains entirely reliant on the implementation of other control measures (after Klein (2011)).

\begin{tabular}{|c|c|c|c|c|}
\hline $\begin{array}{l}\text { Invasive alien } \\
\text { plant taxon }\end{array}$ & $\begin{array}{l}\text { Biological control agents } \\
\text { released }\end{array}$ & $\begin{array}{l}\text { Degree of control } \\
\text { achieved }\end{array}$ & Notes & Key references \\
\hline Acacia cyclops & Seed feeder and flower galler & Substantial & $\begin{array}{l}\text { Predicted that "there will be a substantial and } \\
\text { sustained decline in abundance" of this species } \\
\text { over time, as a result of depleted soil-stored seed } \\
\text { banks }\end{array}$ & $\begin{array}{l}\text { Moran and Hoffmann (2011), Impson } \\
\text { et al. (2011) }\end{array}$ \\
\hline A. dealbata & Seed feeder & Not determined & $\begin{array}{l}\text { Should agents reduce seed output substantially, } \\
\text { mechanical clearing would still be needed to } \\
\text { eliminate existing stands }\end{array}$ & Impson et al. (2011) \\
\hline A. mearnsii & Seed feeder and flower galler & Not determined & $\begin{array}{l}\text { Should agents reduce seed output substantially, } \\
\text { mechanical clearing would still be needed to } \\
\text { eliminate existing stands. Conflict of interest } \\
\text { species, and biological control restricted to agents } \\
\text { that do not damage the vegetative parts of the } \\
\text { plant }\end{array}$ & $\begin{array}{l}\text { Impson et al. (2011), van Wilgen et al. } \\
\text { (2011b) }\end{array}$ \\
\hline A. melanoxylon & Seed feeder & Substantial & $\begin{array}{l}\text { Control agents reduce seed output substantially, } \\
\text { but mechanical clearing needed to eliminate } \\
\text { existing stands. Conflict of interest species, and } \\
\text { biological control restricted to agents that do not } \\
\text { damage the vegetative parts of the plant }\end{array}$ & Impson et al. (2011) \\
\hline A. saligna & $\begin{array}{l}\text { Seed feeder and fungal gall } \\
\text { former }\end{array}$ & Substantial & $\begin{array}{l}\text { Seed production and plant vigour both } \\
\text { considerably reduced, resulting in substantial } \\
\text { declines in dominance }\end{array}$ & $\begin{array}{l}\text { Impson et al. (2011), Moran and } \\
\text { Hoffmann (2011) }\end{array}$ \\
\hline $\begin{array}{l}\text { Caesalpinia } \\
\text { decapetala }\end{array}$ & Seed feeder & Negligible & $\begin{array}{l}\text { This species was not considered as a high priority } \\
\text { for biological control research by Working for } \\
\text { Water }\end{array}$ & Byrne et al. (2011) \\
\hline Cereus jamacaru & Stem sucker and stem borer & Complete & $\begin{array}{l}\text { Mechanical clearing has continued despite the } \\
\text { availability of highly effective biological control } \\
\text { (Table 3) }\end{array}$ & Paterson et al. (2011) \\
\hline $\begin{array}{l}\text { Chromolaena } \\
\text { odorata }\end{array}$ & $\begin{array}{l}\text { Leaf miner, stem borer and } \\
\text { three species of leaf feeders }\end{array}$ & Not determined & $\begin{array}{l}\text { One leaf feeder found to inflict considerable } \\
\text { damage in very localised areas, but, overall, weed } \\
\text { populations have not been suppressed }\end{array}$ & Zachariades et al. (2011a) \\
\hline Eucalyptus species & None & Not applicable & $\begin{array}{l}\text { Many Eucalyptus species are not aggressively } \\
\text { invasive, and this group has not been considered } \\
\text { for biological control }\end{array}$ & None \\
\hline Hakea sericea & $\begin{array}{l}\text { Stem borer, seed feeder, stem } \\
\text { gummosis disease, leaf and } \\
\text { shoot borer, flowerbud feeder } \\
\text { and green-seed feeder }\end{array}$ & Substantial & $\begin{array}{l}\text { Hakea sericea appears to be declining as a result } \\
\text { of the combined effects of mechanical clearing } \\
\text { and biological control }\end{array}$ & $\begin{array}{l}\text { Gordon and Fourie (2011), Esler et al. } \\
\text { (2010) }\end{array}$ \\
\hline Lantana camara & $\begin{array}{l}\text { Thirteen agent species released } \\
\text { and established. Damage to } \\
\text { flowers, leaves and roots }\end{array}$ & $\begin{array}{l}\text { Negligible to } \\
\text { substantial } \\
\text { control, } \\
\text { depending on } \\
\text { plant variety }\end{array}$ & $\begin{array}{l}\text { This species forms hybrids, which complicates } \\
\text { the search for biological control options }\end{array}$ & Urban et al. (2011) \\
\hline Melia azederach & None & Not applicable & $\begin{array}{l}\text { The exact area of origin of Melia azedarach is not } \\
\text { known, so a source of potential biological control } \\
\text { agents cannot be located. }\end{array}$ & None \\
\hline Cactaceae & $\begin{array}{l}\text { Cladode borers, cladode suckers, } \\
\text { stem suckers and stem borers. }\end{array}$ & $\begin{array}{l}\text { Complete ( } 3 \\
\text { species) } \\
\text { Substantial ( } 8 \\
\text { species) } \\
\text { Negligible (1 } \\
\text { species) } \\
\text { Not determined } \\
\text { (2 species) }\end{array}$ & $\begin{array}{l}\text { Fourteen species of Cactaceae (excluding Cereus } \\
\text { jamacaru) have been subjected to biological } \\
\text { control, including the genera } \\
\text { Austrocylindropuntia, Cylindropuntia, Harrisia, } \\
\text { Opuntia and Pereskia. }\end{array}$ & Paterson et al. (2011) \\
\hline Pinus species & None & Not applicable & $\begin{array}{l}\text { Conflict of interest species, and biological control } \\
\text { research restricted to seed feeders }\end{array}$ & Hoffmann et al. (2011) \\
\hline Populus species & None & Not applicable & & None \\
\hline Prosopis species & Seed feeders & Negligible & $\begin{array}{l}\text { Conflict of interest species, and biological control } \\
\text { restricted to seed feeders }\end{array}$ & Zachariades et al. (2011b) \\
\hline Salix babylonica & None & Not applicable & & None \\
\hline $\begin{array}{l}\text { Solanum } \\
\text { mauritianum }\end{array}$ & $\begin{array}{l}\text { Flowerbud feeder and leaf } \\
\text { sucker }\end{array}$ & Negligible & & Olckers, 2011 \\
\hline
\end{tabular}

estimated extent of invasion grew by $363 \%$ between 1990 and 2007 , from about 77,000 condensed ha in 1990 , to 147,000 ha in 2002 , 203,000 ha in 2003 and 360,000 ha in 2007 (van den Berg, 2010). Prosopis trees have some useful properties, and for this reason biological control options have been limited to seed-feeding insects, which only achieve a negligible degree of control (Table 4). Economic studies have indicated, however, that the rapid expansion of Prosopis will result in the value of negative impacts exceeding the value of benefits in the near future, suggesting that a different approach to the control of Prosopis is needed (R. Wise, unpublished data), and that the threat of ongoing invasion by Prosopis species remains a significant concern. Emerging invaders in arid biomes include the torch cactus, Echinopsis spachiana, which has spread from 39 quarter degree squares in 1996 to 75 quarter degree squares in 2011, almost doubling in area. The species has the potential to become a serious threat to ecosystem integrity in arid areas. 


\section{Discussion}

\subsection{The value of control}

Invasive alien plants are often associated with serious negative economic consequences (Pimentel, 2002; Perrings et al., 2010), and preventing or reversing these impacts is the primary goal of invasive alien plant control programs. In South Africa, the economic cost of alien plant invasions at current levels of invasion was estimated to be 6.5 billion rands annually ( 2008 values, De Lange and van Wilgen, 2010); the prevention of such losses, especially those associated with loss of water resources was the primary reason for initiating Working for Water (van Wilgen et al., 2011a). Our assessment suggests, however, that the primary goal of preventing the erosion of ecosystem services is not being consistently met at a national scale. The control operations have in many cases only reached a relatively small percentage of the estimated invaded areas (for example, $4 \%$ of the estimated area under Prosopis invasions in arid areas, $12.6 \%$ of the area estimated area invaded by Pinus in the fynbos biome, and $8 \%$ of $A$. mearnsii invasions in the savanna and grassland biomes). These levels of control have had little apparent impact on the overall state of invasion. Similarly, C. odorata invasions have remained prominent, or grown, despite a substantial portion (38\% of the estimated invaded area in 1996) having been treated in the moist savanna and Indian Ocean coastal biomes. Although progress has been made with the suppression of several invasive taxa, it appears that most biomes remain under threat from several prominent species - notably Pinus in fynbos, Acacia in grassland, savanna and thicket, Prosopis in arid areas, $C$. macrocephalum in grassland and $C$. odorata in the Indian Ocean coastal belt. The overall negative impacts of invasive alien plants may continue to grow therefore, unless more effective solutions can be found.

While the above summary points to a serious problem, it does not mean that control efforts to date have been entirely without benefit. Had the control not taken place, the situation would undoubtedly have been worse. Progress appears to have been made with the mechanical clearing of some species (Table 3), while others have been reduced in extent and impact by a combination of mechanical and biological control (Esler et al., 2010), or, in some cases, biological control alone (Klein, 2011). One estimate suggested that, had no control been carried out, the annual economic losses from alien plant invasions would have been as high as 41.7 billion rands (instead of 6.7 billion rands), and that a substantial portion of these savings (between $5 \%$ and $75 \%$, depending on the group of plants) arose from the biological control of invasive alien plants (De Lange and van Wilgen, 2010). In addition, Working for Water was able to create 20,000 employment opportunities annually over 15 years in impoverished areas, where there would otherwise have been none.

In some areas, where control programs have focussed on smaller areas and adhered to systematic control schedules, substantial progress has been made. For example, invasive alien plants have been substantially reduced over large sections of the formerly densely-invaded Table Mountain National Park (BWvW, personal observation). Nonetheless, our assessment suggests that the strategic approach of a comprehensive program that attempts to target many invasive alien plant species in many areas, using povertyrelief funding, needs to be reassessed if progress is to be made.

\subsection{Socio-political realities}

When South African ecologists first argued for government funding to address the problem of invasive alien plants, their focus was on reducing ecological impacts, notably on water resources. By placing a monetary value on an ecosystem service (rather than on conservation per se), they demonstrated that such an investment would deliver value by protecting the resources vital for development (van Wilgen et al., 1998). The fact that the work could be carried out in a labour-intensive way, thereby creating much-needed employment, was seen as an additional benefit. In reality, very high rates of unemployment, especially among young people, are arguably a far greater problem. The ability of Working for Water to provide employment has become its major attraction to politicians who need to demonstrate that the problem of unemployment is being addressed. This reality constrains Working for Water from allocating appropriate levels of funding to aspects of its operations that would improve its effectiveness in protecting the resources and services that are vital for development and wellbeing. For example, any additional funding directed towards much-needed research, monitoring or assessment would come at the cost of employment. In addition, it is difficult to re-direct resources to new areas when priorities are re-assessed, as that would lead to the loss of employment in lower-priority areas. Even though employment would be created elsewhere, the fact that some workers would have to be disengaged is problematic. There is also a concern that effective biological control could replace the need for labour-intensive clearing. Although it can easily be demonstrated that this concern is unfounded (because such solutions will not be found for all species, and the enormous need for mechanical clearing will remain), it does add to reluctance among some people to re-direct funds towards biological control.

\subsection{Options for increasing effectiveness}

Working for Water's strategic plan (Anonymous, 2007) calls for, among other things, the prioritisation of invasive alien plant species for management action, the development of indicators to underpin a monitoring program, and the implementation of such a program. A start has been made with prioritisation (Nel et al., 2004; van Wilgen et al., 2007, 2008b; Roura-Pascual et al., 2009), but monitoring and evaluation have not been adequately resourced to date. The ongoing attempts to control a wide range of invasive alien plant species in the absence of adequate co-ordination and monitoring has been described as "a strategy of hope" (van Wilgen et al., 2011b). Key missing elements include (1) adequate integration of management interventions (mechanical clearing operations, biological control, and legislative compliance); (2) clear, time-based targets; and (3) protocols for adapting approaches as new information comes to light (van Wilgen et al., 2011b). Several options are available to increase effectiveness by making revisions to the strategic approach that has been adopted to date. These include:

(1) Investing an appropriate portion of funds into the prioritisation of control operations, planning, monitoring and evaluation. Working for Water has arguably initiated too many projects, and targeted too many species in too many areas, to be effective. One study (Roura-Pascual et al., 2009) concluded that "considerable progress in controlling the spread of invasive alien plants in fynbos ecosystems could be achieved by better coordination of management practices and by improving the quality of species distribution data". By setting clear goals, and targeting fewer species in selected priority areas, the available funds could almost certainly be used more effectively.

(2) Improved integration of mechanical and biological control. These two forms of control have seldom been deliberately co-ordinated, as they should be (Wood, 2011). Where this has happened (see, for example Hoffmann et al., 1998), substantial benefits have been reaped. The early release of 
biological control agents to allow establishment, and to affect a reduction in seed output and some suppression of plant growth or populations, before mechanical clearing proceeds can make a substantial contribution to the success of the entire operation. Further benefits could be achieved by targeting emerging weeds (Zimmermann and Neser, 1999; Olckers, 2004) and by rationalising the complex regulatory environment (Klein et al., 2011).

(3) Improving efficiency and professionalism. Working for Water's strategy of investing in the development of relatively inexperienced contractors, to create management capacity, and employing a largely untrained workforce, to alleviate poverty, has brought advantages and disadvantages. The advantages include the delivery of benefits to indigent people in rural areas where few other employment opportunities exist, and gaining political support, and thus substantial funding. The disadvantages include inefficiencies in control operations. Working for Water's records show that up to 9 follow-up visits are have been required for the adequate control of Acacia species in some cases. Part of this is due to a lack of diligence in the application of standard control procedures, but persistent Acacia seed banks, secondary invasions by other species, and the failure to carry out active restoration also play a role (Holmes et al., 2008; Le Maitre et al., 2011). The expenditure of 57.5 million rands on the mechanical clearing of $C$. jamacaru, when biological control options were available to achieve complete control at a minute fraction of the cost (Table 4), provides another example of a significant inefficiency that could arguably have been avoided had a more professional approach been adopted.

(4) Directing a greater portion of the available funding to biological control research, where many successes have been registered (Table 4) and where many more are possible. Currently, spending on biological control is far lower than on other forms of control (about 3\% of the total funds available) despite the significantly better returns on investment from biological control. In their review of the costs and benefits of biological control, van Wilgen and De Lange (2011) noted that "Mechanical and chemical forms of control, while effective in the short term, and often essential components of integrated control, are at best a holding action". It will never be possible to maintain the gains made by mechanical and chemical control in perpetuity, and when funding declines, cleared areas will be re-invaded. Biological control offers the only real hope of maintaining invasive alien plant populations at acceptable levels, at a low enough cost to be sustainable for a very long time. Biological control solutions therefore should be sought and implemented for as many weed species as possible, freeing up scarce resources for the control of invasive plant species for which no biological control options are available.

(5) Promoting a more widespread use of schemes of payment for ecosystem services. Some water utilities and municipalities have contracted Working for Water to control invasive alien plants in their water catchments, using payments for services (in this case water supply to users, Turpie et al., 2008). However, this practice in not widespread enough, and should be encouraged or even made mandatory, as the funding for control operations would both increase and be placed on a more sustainable basis.

(6) Dealing effectively with invasions on privately-owned land. Working for Water's has provided assistance to private landowners by clearing land, with the explicit understanding that landowners would then prevent re-invasion of cleared sites. By and large, landowners have not honoured such agreements, frequently citing Working for Water's inefficiencies (that effectively leave the land in an invaded state - see point 3 above) as a justification for not taking responsibility for ongoing maintenance. As most land in South Africa is in private ownership, a solution to this problem would be essential to the retention of gains made through initial clearing.

(7) Dealing with conflicts. Several important invasive alien plant species (notably trees in the genera Pinus, Acacia and Prosopis) are conflict species, as they bring both benefits and negative impacts. Studies have shown that economic benefits are often exceeded by negative impacts (De Wit et al., 2001; Hoffmann et al., 2011; R. Wise, unpublished data), and that placing constraints on control options (such as biological control) to protect benefits would not deliver the best results in overall economic terms. In such cases, political courage and sustained commitment will be required to ensure sustainable outcomes (through, for example, by allowing expansion of biological control options to more damaging agents, van Wilgen et al., 2011b).

(8) Adopting a framework of adaptive management (Wilhere, 2002; Stankey et al., 2005) to allow for ongoing improvement of management in a complex environment where the outcomes of management cannot be accurately predicted. Adaptive management will require changes to Working for Water's approach, including setting clear and achievable targets, introducing an effective monitoring program to assess progress towards these targets, developing a learning culture, and altering management systems to provide the flexibility to adapt approaches should targets not be met.

Gaining control of invasive species, and reducing their substantial impacts, is an extremely important component of natural resource management. Given the indications presented here that impacts have continued to grow in many areas despite substantial investments in control suggests that changes to the strategy will be needed if significant successes are to be achieved in controlling populations of invasive alien plants in South Africa. The options proposed here must be seen in the light of the sociopolitical environment within which Working for Water has to operate (Section 4.2). In order to persuade political sponsors to re-direct funds to priority interventions, ecologists must demonstrate, convincingly, that the value of invasive alien plant control is greater, in terms of protecting ecosystem services and thus underpinning sustainable development, than its value for creation of employment in control operations alone. This constitutes a major challenge to Working for Water in the immediate future.

\section{Acknowledgements}

We thank the Working for Water programme for funding this assessment. Ilse Koetsee, Hlengiwe Mbatha and Anton Nahman assisted with data processing, and Cliff Moran provided valuable comments on an earlier draft of this paper.

\section{References}

Anonymous, 1999. The National Weeds Strategy: A Strategic Approach to Weed Problems of National Significance, Revised ed. Agriculture and Resource Management Council of Australia and New Zealand, Canberra.

Anonymous, 2007. The Working for Water Programme: Strategic Plan 2008-2012. Working for Water, Cape Town.

Byrne, M.J., Witkowski, E.T.F., Kalibbala, F.N., 2011. Post-release evaluation of Sulcobruchus subsuturalis (Pic) (Coleoptera: Chrysomelidae: Bruchinae), for the biological control of Caesalpinia decapetala (Roth) Alston (Fabaceae) in South Africa. African Entomology 19, 247-257. 
De Lange, W.J., van Wilgen, B.W., 2010. An economic assessment of the contribution of weed biological control to the management of invasive alien plants and to the protection of ecosystem services in South Africa. Biological Invasions 12, 41134124.

De Wit, M., Crookes, D., van Wilgen, B.W., 2001. Conflicts of interest in environmental management: estimating the costs and benefits of a tree invasion. Biological Invasions 3, 167-178.

Esler, K.J., van Wilgen, B.W., te Roller, K.S., Wood, A.R., van der Merwe, J.H., 2010. A landscape-scale assessment of the long-term integrated control of an invasive shrub in South Africa. Biological Invasions 12, 211-218.

Federal Interagency Committee for Management of Noxious and Exotic Weeds, 1998. Pulling Together: A National Strategy for the Management of Invasive Plants, second ed. US Government Printing Office, Washington, DC.

Gordon, A.J., Fourie, A., 2011. Biological control of Hakea sericea Schrad. \& J.C. Wendl. and Hakea gibbosa (Sm.) Cav. (Proteaceae) in South Africa. African Entomology 19, 303-314.

Henderson, L., 1998. Southern African Plant Invaders Atlas (SAPIA). Applied Plant Sciences 12 (31), 32.

Henderson, L., 2007. Invasive, naturalized and casual alien plants in southern Africa: a summary based on the Southern African Plant Invaders Atlas (SAPIA). Bothalia $37,215-248$

Hoffmann, J.H., Moran, V.C., Zeller, D.A., 1998. Long-term population studies and the development of an integrated management programme for control of Opuntia stricta in Kruger National Park, South Africa. Journal of Applied Ecology 35, 156160.

Hoffmann, J.H., Moran, V.C., van Wilgen, B.W., 2011. Prospects for biological control of invasive Pinus species (Pinaceae) in South Africa. African Entomology 19, 393-401.

Holmes, P.M., Esler, K.J., Richardson, D.M., Witkowski, E.T.F., 2008. Guidelines for improved management of riparian zones invaded by alien plants in South Africa. South African Journal of Botany 74, 538-542.

Impson, F.A.C., Kleinjan, C.A., Hoffmann, J.H., Post, J.A., 2008. Dasineura rubiformis (Diptera: Cecidomyiidae), a new biological control agent for Acacia mearnsii in South Africa. South African Journal of Science 104, 247-249.

Impson, F.A.C., Kleinjan, C.A., Hoffmann, J.H., Post, J.A., Wood, A.R., 2011 Biological control of Australian Acacia species and Paraserianthes lophantha (Willd.) Nielsen (Mimosaceae), in South Africa. African Entomology 19, 186207.

Klein, H., 2011. A catalogue of the insects, mites and pathogens that have been used or rejected, or are under consideration, for the biological control of invasive alien plants in South Africa. African Entomology 19, 515-549.

Klein, H., Hill, M.P., Zachariades, C., Zimmermann, H.G., 2011. Regulation and risk assessment for importations and releases of biological control agents against invasive alien plants in South Africa. African Entomology 19, 515-549.

Koenig, R., 2009. Unleashing an army to repair alien-ravaged ecosystems. Science $325,562-563$.

Kotzé, J.D.F., Beukes, B.H., Van den Berg, E.C., Newby, T.S., 2010. National Invasive Alien Plant Survey. Report Number: GW/A/2010/21. Agricultural Research Council: Institute for Soil, Climate and Water, Pretoria.

Kraaij, T., Cowling, R.M., van Wilgen, B.W., 2011. Past approaches and future challenges to the management of fire and invasive alien plants in the new Garden Route National Park. South African Journal of Science 107. doi:10.4102/ sajs.v107i9/10.633

Le Maitre, D.C., Versfeld, D.B., Chapman, R.A., 2000. The impact of invading alien plants on surface water resources in South Africa: a preliminary assessment Water SA 26, 397-408

Le Maitre, D.C., van Wilgen, B.W., Gelderblom, C.M., Bailey, C., Chapman, R.A., Nel J.A., 2002. Invasive alien trees and water resources in South Africa: case studies of the costs and benefits of management. Forest Ecology and Management 160, 143-159.

Le Maitre, D.C., Gaertner, M., Marchante, E., Ens, E.-J., Holmes, P.M., Pauchard, A.M., O'Farrell, P.J., Rogers, A.M., Blanchard, R., Blignaut, J., Richardson, D.M., 2011 Impacts of invasive Australian acacias: implications for management and restoration. Diversity and Distributions 17, 1015-1029.

Levendal, M., Le Maitre, D.C., van Wilgen, B.W., Ntshotso, P., 2008. The development of protocols for the monitoring and evaluation of benefits arising from the working for water programme. Report CSIR/NRE/ECO/ER/2008/0066/C. Council for Scientific and Industrial Research, Stellenbosch.

Macdonald, I.A.W., Jarman, M.L., 1984. Invasive alien organisms in the terrestrial ecosystems of the fynbos biome, South Africa. South African National Scientific Programmes Report 85. Council for Scientific and Industrial Research, Pretoria.

Marais, C., van Wilgen, B.W., Stevens, D., 2004. The clearing of invasive alien plants in South Africa: a preliminary assessment of costs and progress. South African Journal of Science 100, 97-103.

McNeely, J.A., Mooney, H.A., Neville, L.E., Schei, P., Waage, J.K., 2001. A Global Strategy on Invasive Species. IUCN Gland, Switzerland.

Moeller, J., 2010. Spatial Analysis of Pine Tree Invasion in the Tsitsikamma Region, Eastern Cape, South Africa: A Pilot Study. Honours Dissertation. Department of Geography, Rhodes University, Grahamstown.

Mooney, H.A., 2005. Invasive alien species: the nature of the problem. In: Mooney, H.A., Mack, R.N., McNeely, J.A., Neville, L.E., Schei, P.J., Waage, J.K. (Eds.), Invasive Alien Species: A New Synthesis. Island Press, Washington, DC, pp. 1-15.

Moran, V.C., Hoffmann, J.H., 2011. Conservation of the fynbos biome in the Cape Floral Region: the role of biological control in the management of invasive alien trees. BioControl 56. doi:10.1007/s10526-011-9403-5.
Moran, V.C., Hoffmann, J.H., Zimmermann, H.G., 2005. Biological control of invasive alien plants in South Africa: necessity, circumspection, and success. Frontiers in Ecology and the Environment 3, 77-83.

Mucina, L., Rutherford, M.C., 2006. The vegetation of South Africa, Lesotho and Swaziland. Strelitzia 19. South African National Biodiversity Institute, Pretoria.

Nel, J.L., Richardson, D.M., Rouget, M., Mgidi, T.N., Mdzeke, N., Le Maitre, D.C., van Wilgen, B.W., Schonegevel, L., Henderson, L., Neser, S., 2004. A proposed classification of invasive alien plant species in South Africa: towards prioritizing species and areas for management action. South African Journal of Science 100, 53-64.

Olckers, T., 2004. Targeting emerging weeds for biological control in South Africa: the benefits of halting the spread of alien plants at an early stage of their invasion. South African Journal of Science 100, 64-68.

Olckers, T., 2011. Biological control of Solanum mauritianum Scop. (Solanaceae) in South Africa: will perseverance pay off? African Entomology 19, 416-426.

Otten, L., 2010. The Management of Acacia cyclops in the Cape of Good Hope Nature Reserve. Honours Dissertation. Department of Environmental and Geographical Science, University of Cape Town, Cape Town.

Paterson, I.D., Hoffmann, J.H., Klein, H., Mathenge, C.W., Neser, S., Zimmermann, H.G., 2011. Biological control of Cactaceae in South Africa. African Entomology 19, 230-246.

Perrings, C., Mooney, H.A., Williamson, M., 2010. Bioinvasions and Globalization. Oxford University Press, Oxford.

Pimentel, D., 2002. Biological Invasions: Economic and Environmental Costs of Alien Plant, Animal and Microbe Species. CRC Press, Boca Raton.

Roura-Pascual, N., Richardson, D.M., Krug, R., Brown, A., Chapman, R.A., Forsyth, G.G., Le Maitre, D.C., Robertson, M.P., Stafford, L., van Wilgen, B.W., Wessels, N., 2009. Ecology and management of alien plant invasions in South African fynbos: accommodating key complexities in objective decision-making. Biological Conservation 142, 1595-1604.

Simberloff, D., Genovesi, P., Pyšek, P., Campbell, K., 2011. Recognizing conservation success. Science 332, 419.

Stankey, G.H., Clark, R.N., Bormann, B.T., 2005. Adaptive management of natural resources: theory, concepts and institutions. USDA Forest Service, General Technical, Report PNW-GTR-654.

Turpie, J.K., Marais, C., Blignaut, J.N., 2008. The working for water programme: evolution of a payments for ecosystem services mechanism that addresses both poverty and ecosystem service delivery in South Africa. Ecological Economics $65,788-798$.

Urban, A.J., Simelane, D.O., Retief, E., Heystek, F., Williams, H.E., Madire, L.G., 2011. The invasive "Lantana camara L." hybrid complex (Verbenaceae): a review of research into its identity and biological control in South Africa. African Entomology 19, 315-348.

van den Berg, E.C., 2010. Detection, quantification and monitoring Prosopis spp. in the Northern Cape Province of South Africa using Remote Sensing and GIS. Masters Dissertation, North-West University, Potchefstroom.

van Wilgen, B.W., De Lange, W.J., 2011. The costs and benefits of invasive alien plant biological control in South Africa. African Entomology 19, 504-514.

van Wilgen, B.W., Le Maitre, D.C., Cowling, R.M., 1998. Ecosystem services, efficiency, sustainability and equity: South Africa's working for water programme. Trends in Ecology and Evolution 13, 378.

van Wilgen, B.W., Nel, J.L., Rouget, M., 2007. Invasive alien plants and South African rivers: a proposed approach to the prioritization of control operations. Freshwater Biology 52, 711-723.

van Wilgen, B.W., Reyers, B., Le Maitre, D.C., Richardson, D.M., Schonegevel, L., 2008a. A biome-scale assessment of the impact of invasive alien plants on ecosystem services in South Africa. Journal of Environmental Management 89, 336-349.

van Wilgen, B.W., Le Maitre, D.C., Forsyth, G.G., 2008b. The prioritization of species and primary catchments for the purposes of guiding invasive alien plant control operations in the terrestrial biomes of South Africa. Report CSIR/NRE/ECO/ER/ 2008/0070/C, CSIR Natural Resources and the Environment, Stellenbosch.

van Wilgen, B.W., Khan, A., Marais, C., 2011a. Changing perspectives on managing biological invasions: insights from South Africa and the working for water programme. In: Richardson, D.M. (Ed.), Fifty Years of Invasion Ecology: The Legacy of Charles Elton. Wiley-Blackwell, Oxford, pp. 377-393.

van Wilgen, B.W., Dyer, C., Hoffmann, J.H., Ivey, P., Le Maitre, D.C., Richardson, D.M., Rouget, M., Wannenburgh, A., Wilson, J.R.U., 2011b. National-scale strategic approaches for managing introduced plants: insights from Australian acacias in South Africa. Diversity and Distributions 17, 1060-1075.

Versfeld, D.B., Le Maitre, D.C., Chapman, R.A., 1998. Alien invading plants and water resources in South Africa: a preliminary assessment. Report TT 99/98, Water Research Commission, Pretoria.

Wilhere, G.F., 2002. Adaptive management in habitat conservation plans. Conservation Biology 16, 20-29.

Wittenberg, R., Cock, M.J.W., 2005. Best practices for the prevention and management of invasive alien species. In: Mooney, H.A., Mack, R.N., McNeely, J.A., Neville, L.E., Schei, P.J., Waage, J.K. (Eds.), Invasive Alien Species: A New Synthesis. Island Press, Washington, DC, pp. 209-232.

Wood, A., 2011. Integrated control of invasive weeds: clearing operations and biological methods. Environmental Management 6 (4), 17-18.

Zachariades, C., Strathie, L.W., Retief, E., Dube, N., 2011a. Progress towards the biological control of Chromolaena odorata (L.) R.M. King \& H. Rob (Asteraceae) in South Africa. African Entomology 19, 282-302

Zachariades, C., Hoffmann, J.H., Roberts, A., 2011b. Biological control of mesquite (Prosopis species) (Fabaceae) in South Africa. African Entomology 19, 402-415. 
Zimmermann, H.G., Moran, V.C., 1991. Biological control of prickly pear, Opuntia ficus-indica (Cactaceae), in South Africa. Agriculture, Ecosystems and Environment 37, 29-35.

Zimmermann, H.G., Neser, S., 1999. Trends and prospects for biological control of weeds in South Africa. African Entomology. Memoir No. 1, 166-173.
Zimmermann, H.G., Moran, V.C., Hoffmann, J.H., 2004. Biological control of invasive alien plants in South Africa, and the role of the working for water programme. South African Journal of Science 100, 34-40. 